\title{
Somogy megye lószúnyogjainak katalógusa (Diptera: Tipulidae)
}

\author{
TóTH SÁNDOR
}

TóTH S.: Checklist of crane flies of Somogy county (Diptera: Tipulidae)

Abstract: The fauna of crane flies is poorly recorded in Somogy county just like in any other parts of Hungary. According to the available records, 30 species, representing $43 \%$ of the Hungarian fauna, can be proved to exist in the county. Two, relatively rarely occurring species are worth mentioning: Nephrotoma scurra (Meigen, 1818) and Tipula mediterranea (Lackschewitz, 1930).

\section{Bevezetés}

A lószúnyogok Magyarországon a kevésbé kutatott kétszárnyú családok közé tartoznak. Somogy megyére vonatkozó első első adatot Szilády Zoltán a Balaton környék Dipteráinak kutatásával foglalkozó dolgozatában (SzILÁDY 1941) találhatjuk. Ebben a szerzó a Nephrotoma scalaris (Meigen, 1818) fajt említi Balatonszemesról.

A lószúnyogokról az első jelentôsebb adatközlő munka a Természettudományi Múzeum gyújteményének feldolgozásából készült (MANNHEIMS 1966). Ebben a szerzó mintegy 70 fajt mutat ki Magyarország területéról. A közleményben mindössze 3 faj (Tipula couckei Tonnoir, 1921, Tipula lateralis Meigen, 1804, Tipula soósi Mannheims, 1954) somogyi adata található.

A csoport viszonylag jelentôs (de célzottnak nem nevezhető) kutatásáról Somogy megyében csupán a Barcsi Borókásban és a Boronka-melléki Tájvédelmi Körzetben beszélhetünk. A Barcsi Borókás területéról 20 faj előfordulásáról van adatunk. Ebból 19 fajt a szerző (TóTH 1983) közölt, egy faj (Tipula mediterranea Lackschewitz, 1930) pedig egy néhány ritkább fajt tartalmazó országos publikációban (VÁLY 1982) található. A Barcsi Borókás másik említésre méltó, homokterületekhez kötődó ritka faja a Nephrotoma scurra (Meigen, 1818), mely országos ritkasága ellenére, a borókás domináns lószúnyogja. Ez az állat megtalálható egyébként a Boronka-melléki Tájvédelmi Körzetben gyứjtött, 15 fajból álló anyagban is.

A fentiek alapján kereken 30 faj (a hazai taxonok mintegy 43\%-a) alkotja Somogy megye jelenleg ismert lószúnyog faunáját.

$\overline{\text { ISSN 1587-1908 (Print); ISSN 2062-9990 (Online) }}$ 


\section{A Somogyból ismert fajok jegyzéke}

Dictenidia bimaculata (Linnaeus, 1761) Tóth 1983, 1992. Szórványosan előforduló faj, csak néhány hazai lelöhelyét ismeriüu.

Nephrotoma aculeata (Loew, 1871) - Tóth 1983. Föleg hegyvidékekre jellemzó, a síkságon nitka.

Nephrotoma analis (Schummel, 1833) Tóth 1983

Nephrotoma appendiculata (Pierre, 1819) Tóth 1983, 1992

Nephrotoma comicina (Linnaeus, 1758) . Tóth 1992. Szórványos előfordulású.

Nephrotoma flavescens (Linnacus, 1758) Tóth 1992

Nephrotoma quadrifaria (Meigen, 1804) Tóth 1983

Nephrotoma scalaris (Meigen, 1818) Szilády 1941

Nephrotoma scurra (Meigen, 1818) - Tóth 1983, 1992. Szórványosan elóforduló, elsôsorban homokos területekre jellemzô lószúnyog.

Nigrotipula nigra (Linnaeus, 1758) - Tóth 1983,1992 1983

Tanyptera atrata (Linnaeus, 1758) - Tóth

Tipula caesia Schummel, 1833 - Tóth 1992 1966

Tipula couckei Tonnoir, 1921 - Mannheims

Tipula fascipennis Meigen, 1818 - Tóth 1983,1992 1992

Tipula helvola Loew, 1873 - Tóth 1983, 1992

Tipula hortorum Linnaeus, 1758 - Tóth 1966

Tipula lateralis Meigen, 1804 - Mannheims

Tipula livida Van der Vulp, 1858 - Tóth I 983,1992 1992

Tipula lunata Linnaeus, 1758 - Tóth 1983,

Tipula mediterranea Lackschewitz, 1930 . Vály 1982. A fajnak hazánkból ismert a legkeletibb eloofordulása, Dunántúlon (a Bakony kivételével, ahol gyakori) szórványosan található.

Tipula oleracea Linnaeus, 1758 - Tóth 1983

Tipula orientalis Lackschewitz, 1930 - Tóth 1983,1992

Tipula pabulina Meigen, 1818 - Tóth 1983

Tipula paludosa Meigen, 1830 - Tóth 1983

Tipula pierrei Tonnoir in Goetghebuer \& Tonnoir, 1921 - Tóth 1983

Tipula pseudovariipennis Czi冋ek, 1912 Tóth 1983, 1992 1966

Tipula selene Meigen, 1830 - Mannheims

Tipula soósi Mannheims, 1954 Mannheims 1966

Tipula truncata Loew, I873 - Tóth 1992

Tipula vernalis Meigen, 1804 - Tóth 1983

\section{Irodalom}

Mannheims, B. 1966: Die Tipuliden Ungarns (Dipt.) aus der Smmlung des Ungarischen Naturwissenschaftlichen Museums. - Fol. Ent. Hung., 19: 273-283.

SzILÁDY Z. 1941: Diptera kutatás a Balaton környékén-Magyar Biol. Kut. Munk., 13: 259-267. Tóth S. 1983: Adatok a Barcsi Borókás lószúnyog faunájához (Diptera: Tipulidae) - Dunántúli Dolg. Term. tud. Sorozat, 3: 73-78.

TótH S. 1992: Vegyes kétszárnyú (Diptera) adatok a Boronka-melléki Tájpédelmi Körzet faunájához - Dunántúli Dolg. Term. tud. Sorozat, 7: 273-287.

VÁlY Á. 1982: Adatok Magyarország lószúnyogjainak ismeretéhez (Diptera: Tipulidae) - Fol. Ent. Hung., 43: 251-253. 


\title{
Checklist of carne flies of Somogy county (Diptera: Tipulidae)
}

\section{SÁNDOR TÓTH}

The crane fly fauna is poorly recorded in Hungary. The first significant study written on this family was based on the collection of the Museum of Natural History (MANNHEIMS 1966). This paper gives an account of 70 species in the area of Hungary, but refers only to three crane species in Somogy county (Tipula couckei Tonnoir, 1921, Tipula lateralis Meigen, 1804, Tipula soósi Mannheims, 1954). The crane fly fauna is poorly recorded in Somogy county just like in any other parts of Hungary. According to the available records, 30 species, representing $43 \%$ of the Hungarian fauna, can be proved to exist in the county. Due to their rarity, two species are worth mentioning: Nephrotoma scurra (Meigen, 1818) and Tipula mediterranea (Lackschewitz,1930).

\author{
Author's address: \\ Dr. Sándor TótH \\ 8420 - Zirc \\ Széchenyi u. 2. \\ HUNGARY
}

